\title{
ANALYSIS OF THE CUTTING TEMPERATURE AND SURFACE ROUGHNESS DURING THE ORTHOGONAL MACHINING OF AISI 4140 ALLOY STEEL VIA THE TAGUCHI METHOD
}

\author{
ANALIZA TEMPERATURE REZANJA IN HRAPAVOSTI POVRŠINE \\ $S$ TAGUCHI METODO PRI ORTOGONALNI STROJNI OBDELAVI \\ LEGIRANEGA JEKLA AISI 4140
}

\author{
Ali Riza Motorcu', Yahya Isik ${ }^{2}$, Abdil Kus², Mustafa Cemal Cakir ${ }^{3}$ \\ ${ }^{1}$ Çanakkale Onsekiz Mart University, Engineering Faculty, Department of Industrial Engineering, 17100 Çanakkale, Turkey \\ 2Uludağ University, Vocational School of Technical Science Machinery Program, 16059 Bursa, Turkey \\ ${ }^{3}$ Uludağ University, Engineering Faculty, Department of Mechanical Engineering, 16059 Bursa, Turkey \\ armotorcu@comu.edu.tr \\ Prejem rokopisa - received: 2015-01-22; sprejem za objavo - accepted for publication: 2015-06-08
}

doi:10.17222/mit.2015.021

\begin{abstract}
In this research, the tool-chip interface temperature $\left(T_{\mathrm{CTI}}\right)$, the tool temperature $\left(T_{\mathrm{T}}\right)$ and the average surface roughness $\left(R_{\mathrm{a}}\right)$ were measured experimentally during the turning of AISI 4140 alloy steel with TiAlN-TiN, PVD-coated, WNVG 080404-IC907 tungsten carbide inserts using an IR pyrometer technique, a K-type thermocouple and a portable surface-roughness measurement device, respectively. The workpiece material was heat treated by an induction-hardening process and hardened up to a value of $50 \mathrm{HRC}$. The Taguchi method L18 $(21 \times 37)$ was used for the determination of the optimum control factors. The depth of cut, the cutting speed and the feed rate were taken as control factors. The analysis of variance was applied in order to determine the effects of the control factors on the tool-chip interface temperature, the tool temperature and the surface roughness. The optimum combinations of the control factors for $T_{\mathrm{CTI}}, T_{\mathrm{T}}$ and $R_{\mathrm{a}}$ were determined as $a_{2} v_{1} f_{3}, a_{1} v_{3} f_{2}$ and $a_{2} v_{3} f_{1}$, respectively. Second-order predictive models were developed with a linear-regression analysis, and the coefficients of correlation for $T_{\mathrm{CTI}}, T_{\mathrm{T}}$ and $R_{\mathrm{a}}$ were calculated as $R^{2}=92.8, R^{2}=68.1$ and $R^{2}=82.6$, respectively.

Keywords: tool temperature, thermocouple, pyrometer, machining, Taguchi method
\end{abstract}

$\mathrm{V}$ raziskavi so bile eksperimentalno izmerjenene tempetratura na stiku orodje-ostružek $\left(T_{\mathrm{CTI}}\right)$, temperatura orodja $\left(T_{\mathrm{T}}\right)$ in povprečna hrapavost površine $\left(R_{\mathrm{a}}\right)$ pri struženju legiranega jekla AISI 4140, z volfram karbidnimi vložki WNVG 080404-IC907 S PVD prevleko iz TiAlN-TiN, z uporabo IR pirometra, termoelementi vrste K in s prenosnim merilnikom hrapavosti. Obdelovanec je bil toplotno obdelan z indukcijskim ogrevanjem in hlajenjem na trdoto 50 HRC. Za določanje optimalnih kontrolnih faktorjev je bila uporabljena Taguchi metoda L18 $(21 \times 37)$. Globina rezanja, hitrost rezanja in hitrost podajanja so bile vzete kot kontrolni faktorji. Analiza variance je bila uporabljena za določanje vpliva kontrolnih faktorjev na temperaturo prehoda orodje-ostružek, temperaturo orodja in hrapavost površine. Določene so bile optimalne kombinacije kontrolnih faktorjev za $T_{\text {CTI }}, T_{\mathrm{T}}$ in $R_{\mathrm{a}}$, kot $a_{2} v_{1} f_{3}, a_{1} v_{3} f_{2}$ and $a_{2} v_{3} f_{1}$. Z linearno regresijsko analizo so bili razviti modeli drugega reda za napovedovanje in izračunani so bili koeficienti korelacije za $T_{\mathrm{CTI}}, T_{\mathrm{T}}$ in $R_{\mathrm{a}}$ kot $R^{2}=92,8, R^{2}=68,1$ in $R^{2}=82,6$.

Ključne besede: temperatura orodja, termočlen, pirometer, strojna obdelava, Taguchi metoda

\section{INTRODUCTION}

In order to overcome the difficulties in terms of efficiency and the quality of production encountered in the metal-cutting industries, all the stages of the machining process need to be monitored. During the metal-cutting processes, one of the key factors is the cutting temperature, which directly affects the surface quality, the tool wear, the tool life, and the cost of production. The amount of heat generated varies with the type of material being machined and the cutting parameters (especially the cutting speed, which had the biggest influence on the temperature). ${ }^{1}$

Temperature monitoring is one of the most difficult and complicated procedures in metal-cutting operations. It is extremely complex to develop a model for measuring the temperature due to the complexity of the different events at the point of contact between the tool and the workpiece. Therefore, an accurate and repeatable temperature prediction still remains as a challenge due to this complexity of the contact phenomenon. ${ }^{2}$ It is quite difficult to measure the temperature since the heat in the region is very close to the cutting edge. Due to a lack of sufficient experimental data, it is not possible to verify a mathematical model. Numerous attempts have been made to measure the temperature during machining operations. $^{3}$

Amongst the many experimental methods to measure the temperature directly, only a few systems have used the temperature as an indicator of machine performance and for industrial applications. ${ }^{4}$ Therefore, the temperature can be controlled using the appropriate cutting parameters to design and develop the system and it will be beneficial to increase the efficiency in production.

In recent years, experimental studies related to metal-cutting processes have made use of the Taguchi 
method. This method has been used successfully for a determination of the appropriate cutting parameters and in the optimization of parameters related to tool wear, tool life, and the surface quality. The Taguchi method and Analysis of Variance (ANOVA) can conveniently optimize the cutting parameters with several experimental runs that are well designed. Taguchi parameter design can optimize the performance characteristics through the settings of the design parameters and reduce the sensitivity of the system's performance to the source of variation. ${ }^{5}$ On the other hand, ANOVA is used to identify the most significant variables and interaction effects. ${ }^{6,7}$

In the Taguchi method, quality is measured by the deviation of a quality characteristic from its target value. Therefore, the objective is to create a design that is insensitive to all possible combinations of uncontrollable factors and is at the same time effective and cost efficient as a result of setting the key controllable factors at their optimum levels. ${ }^{8}$ Taguchi's parameter design offers a simple and systematic approach that can reduce the number of experiments to optimize the design for performance, quality and cost. The signal-to-noise $(S / N)$ ratio and the orthogonal array $(O A)$ are two major tools used in robust design. ${ }^{9}$

A lot of research has been conducted for determining the optimal cutting parameters. W. H. Yang and Y. S. Tarng ${ }^{10}$ employed the Taguchi method, and the optimal cutting parameters for the turning of S45C steel bars were successfully obtained. B. M. Gopalsamy et al. ${ }^{11}$ applied the Taguchi method to find the optimum machining parameters while machining hard steel and used the L18 orthogonal array. The $S / N$ ratio and ANOVA were used to study the performance characteristics of the machining parameters. F. Ficici et al. ${ }^{12}$ used the Taguchi method to study the wear behaviour of boronized AISI 1040 steel. They used the $S / N$ ratio to investigate the optimum setting parameters.

M. Adinarayana et al. ${ }^{13}$ presented the multi-response optimization of the turning parameters for the turning of AISI 4340 alloy steel. The experiments were designed and conducted based on Taguchi's L27 orthogonal array design. They discussed an investigation into the use of Taguchi parameter design to predict and optimize the surface roughness, the metal removal rate and the power consumption during turning operations. E. D. Kirby ${ }^{14}$ discussed an investigation into the use of Taguchi parameter design for optimizing the surface roughness generated by a CNC turning operation. He used a standard orthogonal array for determining the optimum turning parameters with an applied noise factor. The controlled factors include the spindle speed, the feed rate, and the depth of cut.

In this paper, the measurement of temperature during the turning of AISI 4140 alloy steel was performed using various cutting parameters. The tool-chip interface temperature $T_{\text {Стг }}$ was measured by infrared thermometer, the tool temperature $T_{\mathrm{T}}$ was measured with a K-type thermocouple in the cutting zone, and the average surface roughness $R_{\mathrm{a}}$ was measured using a portable surface-roughness measurement device. The Taguchi design was selected to find the relationships between the control factors. The depth of cut $\left(a_{\mathrm{p}}\right)$, the cutting speed $\left(v_{\mathrm{c}}\right)$, and the feed rate $(f)$ were taken as the control factors.

\section{TEMPERATURES DURING METAL CUTTING}

In the cutting process, nearly all of the energy dissipated during plastic deformation is converted into heat, which in turn raises the temperature in the cutting zone. Since the heat generation is closely related to the plastic deformation and friction, we can specify three main sources of heat when cutting:

- plastic deformation by shearing in the primary shear zone;

- friction on the cutting face and friction between the chips;

- tool on the tool flank.

Temperature results in dimensional errors on the machined surface. The cutting tool elongates as a result of the increased temperature, and the position of the cutting tool edge shifts towards the machined surface, resulting in a dimensional error of about $0.01-0.02 \mathrm{~mm}$. Since the processes of thermal generation, dissipation, and solid-body thermal deformation are all transient, some time is required to achieve the steady-state condition.

Heat is mostly dissipated by: the discarded chip that carries away about $60-80 \%$ of the total heat, the workpiece acts as a heat sink drawing away 10-20\% of heat, while the cutting tool draws away $\sim 10 \%$ of the heat. The balance between heat generation and heat dissipation during metal cutting is shown in Figure 1.

\section{MATERIALS AND METHOD}

\subsection{Workpiece and cutting tool}

The workpiece material is AISI 4140 alloy steel. The chemical composition of the workpiece material (in volume fractions) is shown in Table $\mathbf{1}$. The machining process was performed using a NR 2020K-08 tool holder

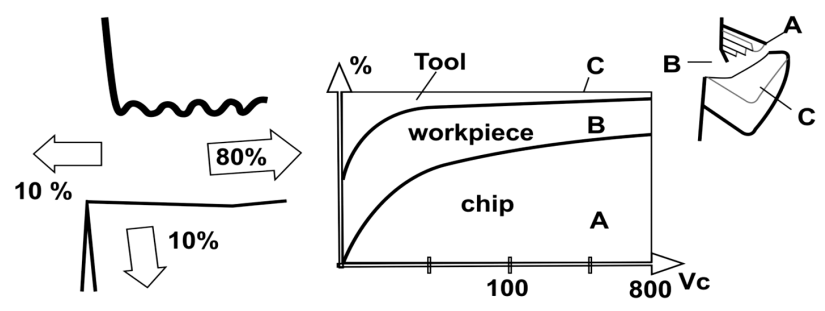

Figure 1: The balance of heat generation and heat dissipation during metal cutting

Slika 1: Izravnava med sproščeno in odvedeno toploto pri rezanju kovin 


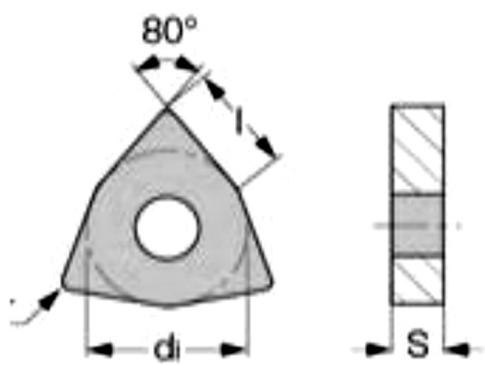

Figure 2: Schematic of tip geometry Slika 2: Shema geometrije rezilne konice

and a TiAlN-TiN, PVD-coated, WNVG 080404-IC907 solid carbide insert. Figure 2 and Table 2 show a schematic of the tip geometry and the specifications of the insert.

Table 1: Chemical composition of AISI 4140 alloy steel (in volume fractions, $x / \%$ )

Tabela 1: Kemijska sestava legiranega jekla AISI 4140 (v volumenskih odstotkih, $x / \%$ )

\begin{tabular}{|c|c|c|c|c|c|c|c|}
\hline $\mathrm{C}$ & $\mathrm{Cr}$ & $\mathrm{Ni}$ & $\mathrm{Mn}$ & $\mathrm{P}$ & $\mathrm{S}$ & $\mathrm{Si}$ & $\mathrm{Mo}$ \\
\hline 0.38 & 0.80 & 9.58 & 0.75 & 0.035 & 0.04 & 0.15 & 0.15 \\
\hline
\end{tabular}

Table 2: The specifications of the insert

Tabela 2: Specifikacije vložka za rezanje

\begin{tabular}{|c|c|c|c|c|c|c|}
\hline \multicolumn{3}{|c|}{ TiAlN-TiN PVD-coated WNVG 080404-IC907 } \\
\hline$d_{1}$ & $S$ & $I$ & $r$ & HRA & TRS & $d$ \\
\hline 12.70 & 4.83 & 8.70 & 0.40 & 92.80 & 560 & 4.70 \\
\hline \multicolumn{3}{|c|}{ Property } & \multicolumn{4}{c|}{ Value } \\
\hline ISO Range - P/M/K & \multicolumn{3}{c|}{$(\mathrm{H} 10$-P30)-H15)(M05-M20) } \\
\hline ISO Range - H/S/N & \multicolumn{3}{c|}{ PVD } \\
\hline Grade or coating type & \multicolumn{3}{c|}{ TiAlN-TiN } \\
\hline Coating layers & \multicolumn{3}{c}{} \\
\hline
\end{tabular}

\subsection{Experimental conditions, temperature and sur- face-roughness measurements}

In this study, two methods of tool-temperature evaluation are presented:

- the placement of the K-type thermocouple on the tool,

- the infrared pyrometer.

A schematic view of the experimental setup is shown in Figure 3. Cylindrical workpieces $(\varnothing 45 \times 300 \mathrm{~mm})$ were fixed between the chuck and the tailstock and were pre-machined using a separate insert. The workpiece samples were heat treated by induction hardening and a hardness of $50 \mathrm{HRC}$ was maintained. The samples were then solution heat treated and oil quenched in order to achieve the proper hardness.

In this study, an Optris CF4 infrared thermometer was used to measure $T_{\mathrm{CTI}}$. The maximum temperature (which was about $525{ }^{\circ} \mathrm{C}$ ) was recorded around the cutting zone. A total of 18 trials were conducted throughout these experiments and brand new inserts were used for each temperature measurement. Hence, the cutting temperature increased with the cutting speed, the

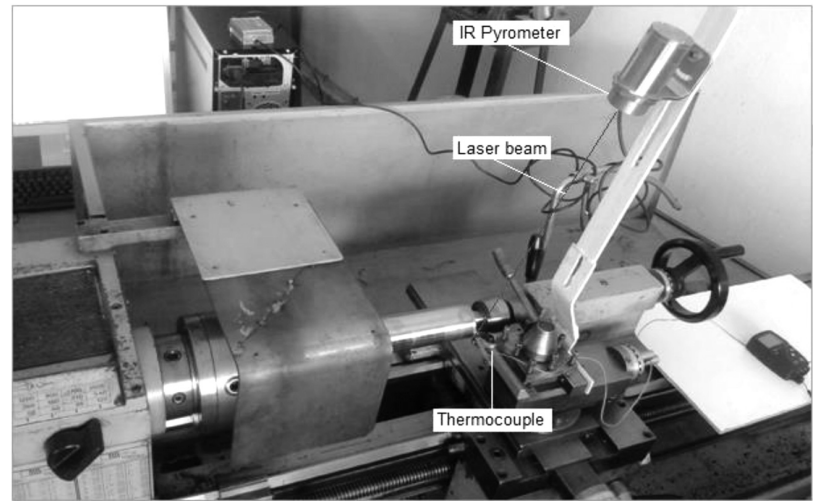

Figure 3: Thermocouple and IR pyrometer connections to the lathe Slika 3: Povezava termočlena in IR-pirometra na stružnici

feed rate and the depth of cut. The experiments were repeated three times for the same cutting conditions and the measured values were averaged. $T_{\mathrm{T}}$ was measured using a K-type thermocouple. The thermocouple measurements were recorded every five seconds.

The $R_{\mathrm{a}}$ surface roughness was measured to characterize the surface quality. The $R_{\mathrm{a}}$ measurements were carried out using a Time TR 200 device by obtaining values from different points that were parallel to the workpiece axis at a cut-off length of $5.6 \mathrm{~mm}$. According to the experimental design, three measurements were made on the surfaces at the specified values of the control factors, and the $R_{\mathrm{a}}$ values were determined by taking the average of the measurement results.

\subsection{Experimental design using the Taguchi method}

The Taguchi design was selected to find the relationships between the control factors and the quality characteristics. The cutting speed $\left(v_{\mathrm{c}}\right)$, feed rate $(f)$ and depth of cut $\left(a_{\mathrm{p}}\right)$, whose levels are given Table $\mathbf{3}$, were selected as the control factors. The quality characteristics were the tool-chip interface temperature $\left(T_{\mathrm{CTI}}\right)$, the tool temperature $\left(T_{\mathrm{T}}\right)$ and the average surface roughness $\left(R_{\mathrm{a}}\right)$. As the total degree of freedom of the factor group was 5 , a standard Taguchi experimental plan with the notation L18 $\left(2_{1} \times 3_{7}\right)$ was chosen as the orthogonal array. The rows in the L18 orthogonal array used in the experiment corresponded to each trial and the columns contained the factors to be studied. The first column consists of the depth of cut; the second and the third columns contain the cutting speed and the feed rate, respectively. In the Taguchi method, the experimental results are transformed into a $S / N$ ratio. The $S / N$ ratio is used while approaching or moving away from the desired value and measuring the quality characteristics. ${ }^{15-18}$ The smaller-isbetter (SB), the nominal-best (NB) and the larger-isbetter (LB) approaches are found according to the results of the $S / N$ ratio. ${ }^{15-18}$ As the tool-chip interface temperature $\left(T_{\mathrm{CTI}}\right)$, the tool temperature $\left(T_{\mathrm{T}}\right)$ and the surface roughness $\left(R_{\mathrm{a}}\right)$ values were required to be the lowest, the $S / N$ ratios of these quality characteristics were calculated in $\mathrm{dB}$ using Equation (1) according to the SB option in the study..$^{15-18}$ 
A. R. MOTORCU et al.: ANALYSIS OF THE CUTTING TEMPERATURE AND SURFACE ROUGHNESS ...

$$
S / N_{\mathrm{SB}}=-10 \cdot \lg \left(\frac{1}{2} \sum_{i=1}^{n} y_{i}^{2}\right)
$$

In the Equation (1), $n$ is the number of the experiment and $y i$ is the $i$ th data point obtained..$^{15-18}$ ANOVA was applied in order to determine the percentage effects of the control factors on $T_{\mathrm{CTI}}, T_{\mathrm{T}}$ and $R_{\mathrm{a}}$.

Table 3: Control factors and their levels

Tabela 3: Kontrolni faktorji in njihovi nivoji

\begin{tabular}{|c|c|c|c|c|c|c|}
\hline $\begin{array}{c}\text { Sym- } \\
\text { bol }\end{array}$ & $\begin{array}{c}\text { Control } \\
\text { factors }\end{array}$ & Unit & $\begin{array}{c}\text { Level } \\
1\end{array}$ & $\begin{array}{c}\text { Level } \\
2\end{array}$ & $\begin{array}{c}\text { Level } \\
3\end{array}$ & $\begin{array}{c}\text { Degree of } \\
\text { freedom } \\
\text { (DoF) }\end{array}$ \\
\hline$a_{\mathrm{p}}$ & $\begin{array}{c}\text { Depth of } \\
\text { cut }\end{array}$ & $\mathrm{mm}$ & 0.40 & 0.60 & - & 1 \\
\hline$v_{\mathrm{c}}$ & $\begin{array}{c}\text { Cutting } \\
\text { speed }\end{array}$ & $\mathrm{m} / \mathrm{min}$ & 76 & 114 & 170 & 2 \\
\hline$f$ & Feed rate & $\mathrm{mm} / \mathrm{rev}$ & 0.05 & 0.08 & 0.12 & 2 \\
\hline
\end{tabular}

\subsection{Predictive models for temperature and surface roughness with multiple regression analysis}

Equations were developed for the prediction of $T_{\mathrm{CTI}}$, $T_{\mathrm{T}}$ and $R_{\mathrm{a}}$ using the experimental results in a multiple regression analysis. The second-order linear models containing the main effects of the control factors and their interactions are signified with the Equation (2):

$$
\begin{aligned}
& Y_{1}=y-\varepsilon=b_{0} x_{0}+b_{1} x_{1}+b_{2} x_{2}+ \\
& +b_{3} x_{3}+b_{4} x_{12}+b_{5} x_{13}+b_{6} x_{23}
\end{aligned}
$$

where $Y_{1}$ is the estimated answer of the second-order equation and $y$ is the tool-chip interface temperature $\left(T_{\mathrm{CTI}}\right)$, tool temperature $\left(T_{\mathrm{T}}\right)$ or surface roughness $\left(R_{\mathrm{a}}\right)$ measured on a the logarithmic scale, $x_{0}=1$ is the fixed variable, the $x_{1}, x_{2}$ and $x_{3}$ control factors are the logarithmic transformations of the depth of cut, the cutting speed and the feed rate and, the $x_{12}, x_{13}$ and $x_{23}$ interactions of the control factors are the logarithmic transformations of the depth of cut-cutting speed, the depth of cut-feed rate and cutting speed-feed rate. The coefficient of the experimental error is $\varepsilon$, and the $b$ values $\left(b_{0}, b_{1}, b_{2}, b_{3}, b_{4}, b_{5}\right.$ and $\left.b_{6}\right)$ are the coefficients of related factors.

\section{ANALYSIS OF THE RESEARCH RESULTS}

The present study was performed to understand and evaluate the infrared- and thermocouple-based temperature measurements during metal cutting and to consider the practical difficulties. $T_{\mathrm{CTI}}, T_{\mathrm{T}}$ and $R_{\mathrm{a}}$ were used as the quality characteristics. The experimental results are shown in Table 4.

The $T_{\text {СТI }}, T_{\mathrm{T}}$ and $R_{\mathrm{a}}$ measurement results from the turning of the quenched and tempered AISI 4140 steel with coated carbide tools were resolved and analyzed by means of the Minitab 16.0 package software. From Table 4 it is clear that the overall means for $T_{\mathrm{CTI}}, T_{\mathrm{T}}$ and $R_{\text {a }}$ were calculated as $446.11^{\circ} \mathrm{C}, 70.78{ }^{\circ} \mathrm{C}$ and $0.578 \mu \mathrm{m}$, respectively.
Table 4: The experimental results for the quality characteristics and

\begin{tabular}{|c|c|c|c|c|c|c|c|c|c|}
\hline \multirow[b]{2}{*}{$\begin{array}{c}\text { Exp. } \\
\text { no }\end{array}$} & \multicolumn{3}{|c|}{$\begin{array}{l}\text { Control } \\
\text { factors }\end{array}$} & \multicolumn{3}{|c|}{ Measured values } & \multicolumn{3}{|c|}{$S / N$ Ratios $(\mathrm{dB})$} \\
\hline & $a_{\mathrm{p}}$ & $v_{\mathrm{c}}$ & $f$ & $\begin{array}{c}\text { Tool- } \\
\text { chip in- } \\
\text { terface } \\
\text { tempera- } \\
\text { ture, } T_{\text {CTI }} \\
\left({ }^{\circ} \mathrm{C}\right)(\mathrm{IR} \\
\text { Pyro- } \\
\text { meter) }\end{array}$ & $\begin{array}{c}\text { Tool } \\
\text { tempera- } \\
\text { ture, } T_{\mathrm{T}} \\
\left({ }^{\circ} \mathrm{C}\right) \\
(\text { Thermo- } \\
\text { couple) }\end{array}$ & $\begin{array}{l}\text { Surface } \\
\text { rough- } \\
\text { ness, } R_{\mathrm{a}} \\
(\mu \mathrm{m})\end{array}$ & $\begin{array}{l}S / N \\
T_{\text {CTI }}\end{array}$ & $\begin{array}{c}S / N \\
T_{\mathrm{T}}\end{array}$ & $\begin{array}{c}S / N \\
R_{\mathrm{a}}\end{array}$ \\
\hline 1 & 0.4 & 76 & 0.05 & 410 & 57 & 0.295 & -52.26 & -35.12 & 10.60 \\
\hline 2 & 0.4 & 76 & 0.08 & 405 & 66 & 0.483 & -52.15 & -36.39 & 6.32 \\
\hline 3 & 0.4 & 76 & 0.12 & 410 & 72 & 0.958 & -52.26 & -37.15 & 0.37 \\
\hline 4 & 0.4 & 114 & 0.05 & 460 & 65 & 0.484 & -53.26 & -36.26 & 6.30 \\
\hline 5 & 0.4 & 114 & 0.08 & 465 & 61 & 0.579 & -53.35 & -35.71 & 4.75 \\
\hline 6 & 0.4 & 114 & 0.12 & 425 & 67 & 0.988 & -52.57 & -36.52 & 0.10 \\
\hline 7 & 0.4 & 170 & 0.05 & 520 & 65 & 0.410 & -54.32 & -36.26 & 7.74 \\
\hline 8 & 0.4 & 170 & 0.08 & 500 & 67 & 0.492 & -53.98 & -36.52 & 6.16 \\
\hline 9 & 0.4 & 170 & 0.12 & 475 & 71 & 0.872 & -53.53 & -37.03 & 1.19 \\
\hline 10 & 0.6 & 76 & 0.05 & 400 & 72 & 0.489 & -52.04 & -37.15 & 6.21 \\
\hline 11 & 0.6 & 76 & 0.08 & 390 & 80 & & -51.82 & -38.06 & 5.51 \\
\hline 12 & 0.6 & 76 & 0.12 & 395 & 76 & 0.720 & -51.93 & -37.62 & 2.85 \\
\hline 13 & 0.6 & 114 & 0.05 & 430 & 80 & 0.429 & -52.67 & -38.06 & 7.35 \\
\hline 14 & 0.6 & 114 & 0.08 & 435 & 75 & 0.547 & -52.77 & -37.50 & 5.24 \\
\hline 15 & 0.6 & 114 & 0.12 & 420 & 83 & 0.722 & -52.46 & -38.38 & 2.83 \\
\hline 16 & 0.6 & 170 & 0.05 & 485 & 81 & 0.354 & -53.71 & -38.17 & 9.02 \\
\hline 17 & 0.6 & 170 & 0.08 & 525 & 67 & 0.406 & -54.40 & -36.52 & 7.83 \\
\hline 18 & 0.6 & 170 & 0.12 & 480 & 69 & 0.643 & -53.62 & -36.78 & 3.84 \\
\hline
\end{tabular}
$S / N$ ratios

Tabela 4: Rezultati preizkusov za opis kvalitete in $S / N$ razmerja

Overall mean of $T_{\mathrm{CTI}}=446.11^{\circ} \mathrm{C}, S / N$ ratio of $T_{\mathrm{CTI}}=-52.95 \mathrm{~dB}$ Overall mean of $T_{\mathrm{T}}=70.78{ }^{\circ} \mathrm{C}, S / N$ ratio of $T_{\mathrm{CTI}}=-36.95 \mathrm{~dB}$ Overall mean of $R_{\mathrm{a}}=0.578 \mu \mathrm{m}, S / N$ ratio of $R_{\mathrm{a}}=5.24 \mathrm{~dB}$

The variation of the tool temperature and the toolchip interface temperature with the cutting parameters are shown in Figures $\mathbf{4 a}$ and $\mathbf{4 b}$. Obviously, it is clear that the tool-chip interface temperature and the tool temperature increase with an increase in the cutting speed (Figure 4a). The influence of the tool temperature and the feed rate on the surface roughness is shown in Figure 5a. It was observed that the lowest feed rate produced a better surface quality. The experiments showed that the cutting speed and the feed rate are the main factors affecting the surface roughness (Figure 5b).

\subsection{Analysis of the control factors for the temperature and surface roughness}

The responses for the $S / N$ ratios (smaller is better) of $T_{\mathrm{CTI}}, T_{\mathrm{T}}$ and $R_{\mathrm{a}}$ are presented in Table 5 and the responses for the means in Table $\mathbf{6}$. While the signal value represents the real desired value that the system gives and which is to be measured, the noise factor represents the portion of the undesired factors in the measured value. The $S / N$ ratio analysis provided significant information about the nature of the process of turning hardened AISI 4140 steel with coated carbide cutting tools under selected conditions. The fact that the differences between the highest and the lowest $S / N$ ratio values of each control factor calculated at different levels 
A. R. MOTORCU et al.: ANALYSIS OF THE CUTTING TEMPERATURE AND SURFACE ROUGHNESS ...

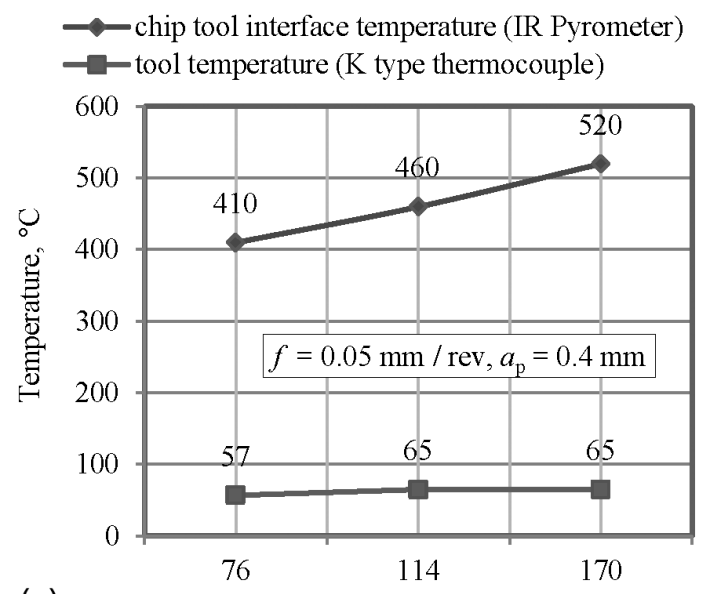

(a) Cutting speed, $\mathrm{m} / \mathrm{min}$

tool temperature ( $\mathrm{K}$ type thermocouple)

chip tool interface temperature (IR pyrometer)

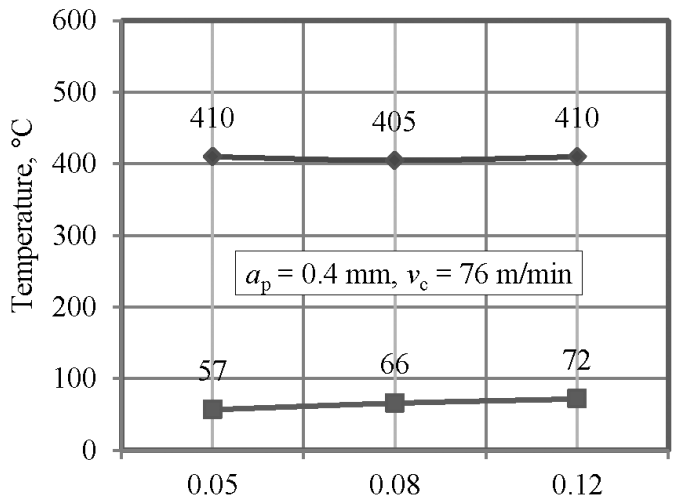

(b)

Feed rate, $\mathrm{mm} / \mathrm{rev}$

Figure 4: The influence of cutting speed and feed rate on the temperature: a) cutting speed, b) feed rate

Slika 4: Vpliv hitrosti rezanja in hitrosti podajanja na temperaturah: a) hitrost rezanja, b) hitrost podajanja

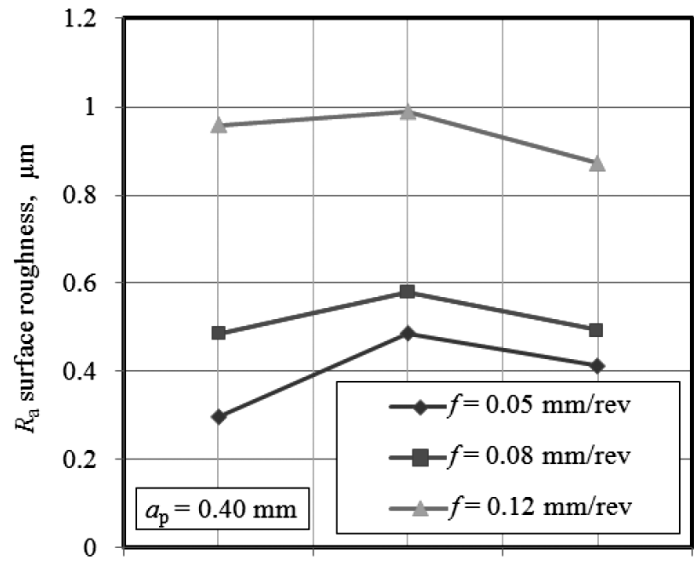

(a) 405 Tool temperature, ${ }^{\circ} \mathrm{C}$

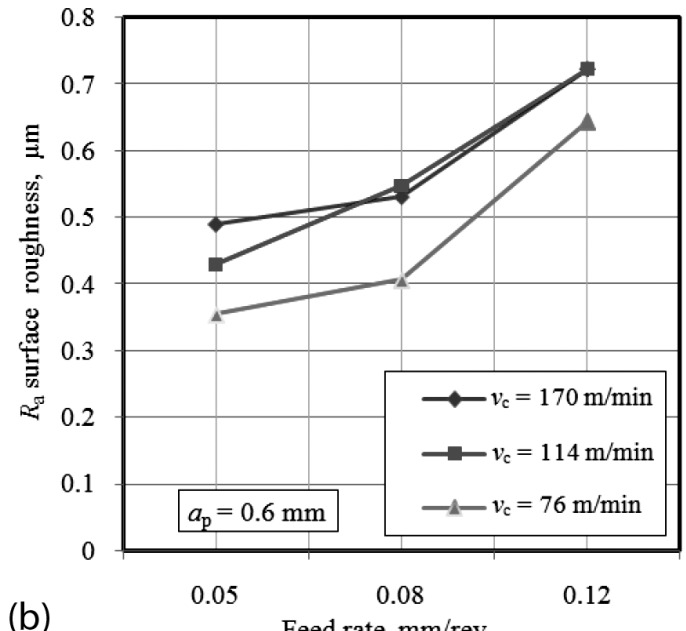

(b)

Feed rate, $\mathrm{mm} / \mathrm{rev}$

Figure 5: Influence of tool temperature and feed rate on surface roughness: a) tool temperature, b) feed rate

Slika 5: Vpliv temperature orodja in hitrosti podajanja na hrapavost površine: a) temperatura orodja, b) hitrost podajanja

Table 5: Response table for $S / N$ ratios (smaller is better) of $T_{\mathrm{CTI}}, T_{\mathrm{T}}$ and $R_{\mathrm{a}}$

Tabela 5: Razpredelnica odgovorov za $S / N$ razmerja (manjše je boljše) za $T_{\mathrm{CTI}}, T_{\mathrm{T}}$ in $R_{\mathrm{a}}$

\begin{tabular}{|c|c|c|c|c|c|c|c|c|c|}
\hline \multirow{2}{*}{ Level } & \multicolumn{3}{|c|}{ Tool-chip interface temperature, $T_{\mathrm{CTI}}$} & \multicolumn{3}{c|}{ Tool temperature, $T_{\mathrm{T}}(\mathrm{dB})$} & \multicolumn{3}{c|}{ Surface roughness, $R_{\mathrm{a}}(\mathrm{dB})$} \\
\hline & $a_{\mathrm{p}}$ & $v_{\mathrm{c}}$ & $f$ & $a_{\mathrm{p}}$ & $v_{\mathrm{c}}$ & $f$ & $a_{\mathrm{p}}$ & $v_{\mathrm{c}}$ & $f$ \\
\hline 1 & -53.07 & -52.08 & -53.04 & -36.33 & -36.91 & -36.84 & 4.838 & 5.313 & 7.873 \\
\hline 2 & -52.83 & -52.85 & -53.08 & -37.58 & -37.07 & -36.78 & 5.632 & 4.429 & 5.969 \\
\hline 3 & - & -53.93 & -52.73 & - & -36.88 & -37.24 & - & 5.963 & 1.864 \\
\hline$\Delta$ & 0.25 & 1.85 & 0.35 & 1.25 & 0.19 & 0.46 & 0.793 & 1.534 & 6.008 \\
\hline Rank & 3 & 1 & 2 & 1 & 3 & 2 & 3 & 2 & 1 \\
\hline
\end{tabular}

Table 6: Response table for means of $T_{\mathrm{CTI}}, T_{\mathrm{T}}$ and $R_{\mathrm{a}}$

Tabela 6: Tabela odgovorov za pomen $T_{\mathrm{CTI}}, T_{\mathrm{T}}$ in $R_{\mathrm{a}}$

\begin{tabular}{|c|c|c|c|c|c|c|c|c|c|}
\hline \multirow{2}{*}{ Level } & \multicolumn{3}{|c|}{ Tool-chip interface temperature, $T_{\mathrm{CTI}}$} & \multicolumn{2}{c|}{ Tool temperature, $T_{\mathrm{T}}\left({ }^{\circ} \mathrm{C}\right)$} & \multicolumn{3}{c|}{ Surface roughness, $R_{\mathrm{a}}(\mu \mathrm{m})$} \\
\hline & $a_{\mathrm{p}}$ & $v_{\mathrm{c}}$ & $f$ & $a_{\mathrm{p}}$ & $v_{\mathrm{c}}$ & $f$ & $a_{\mathrm{p}}$ & $v_{\mathrm{c}}$ & $f$ \\
\hline 1 & 452.2 & 401.7 & 450.8 & 65.67 & 70.50 & 70.00 & 0.6179 & 0.5792 & 0.4102 \\
\hline 2 & 440.09 & 439.2 & 453.3 & 75.89 & 71.83 & 69.33 & 0.5378 & 0.6248 & 0.5062 \\
\hline 3 & - & 497.5 & 434.2 & - & 70.00 & 73.00 & - & 0.5295 & 0.8172 \\
\hline$\Delta$ & 12.2 & 95.8 & 19.2 & 10.22 & 1.83 & 3.67 & 0.0801 & 0.0953 & 0.4070 \\
\hline Rank & 3 & 1 & 2 & 1 & 3 & 2 & 3 & 2 & 1 \\
\hline
\end{tabular}


are higher or lower was used in the determination of the factors effective on $T_{\text {CTI }}, T_{\mathrm{T}}$ and $R_{\mathrm{a}}$. The most effective parameters on $T_{\text {СТ }}$ were the cutting speed, the feed rate and the depth of cut because there were $(1.85,0.35$ and $0.25) \mathrm{dB}$ differences between their levels (Table 5). The most effective parameters on $T_{\mathrm{T}}$ were determined to be the depth of cut, the feed rate and the cutting speed, with differences of $(1.25,0.46$ and 0.19$) \mathrm{dB}$, respectively (Table 5). The most effective parameters on $R_{\mathrm{a}}$ were determined to be the feed rate, the cutting speed and the depth of cut, with differences of $(6.008,1.534$ and 0.793$) \mathrm{dB}$, respectively (Table 5). The optimum values for the surface roughness and the dimensional accuracy were reported to be $a_{2} v_{1} f_{3}, a_{1} v_{3} f_{2}$ and $a_{2} v_{3} f_{1}$, respectively (Table 6).

The main effects of the control factors on the performance characteristics during the turning of the quenched and tempered AISI 4140 steel with coated carbide cutting tools were demonstrated using the "Graphical Representation of Factor Effects" and evaluated..$^{8-11}$ The main effect graphs showing the effects of the control factors on $T_{\text {СТI }}, T_{\mathrm{T}}$ and $R_{\mathrm{a}}$ are given in Figures 6 and 7, respectively.

In Figure 6, the optimum levels of the control factors for the tool-chip interface temperature are $a_{2}\left(a_{\mathrm{p}}=0.6\right.$

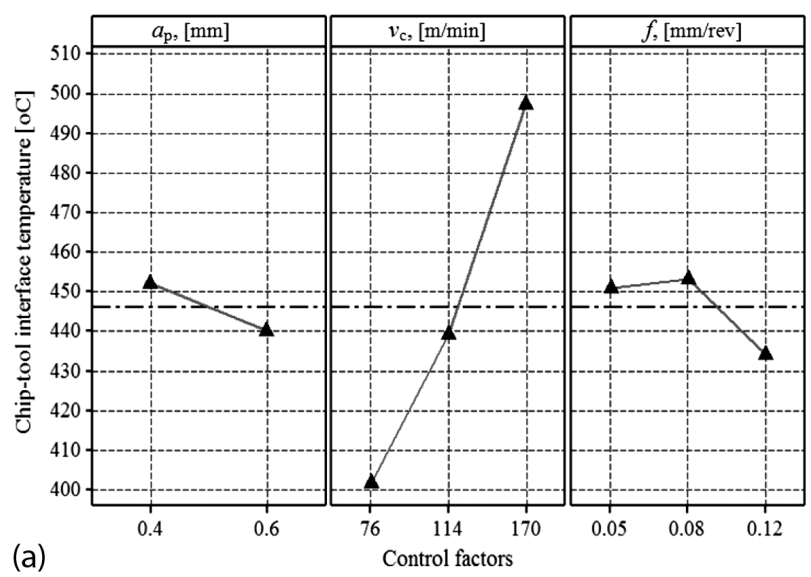

(a)

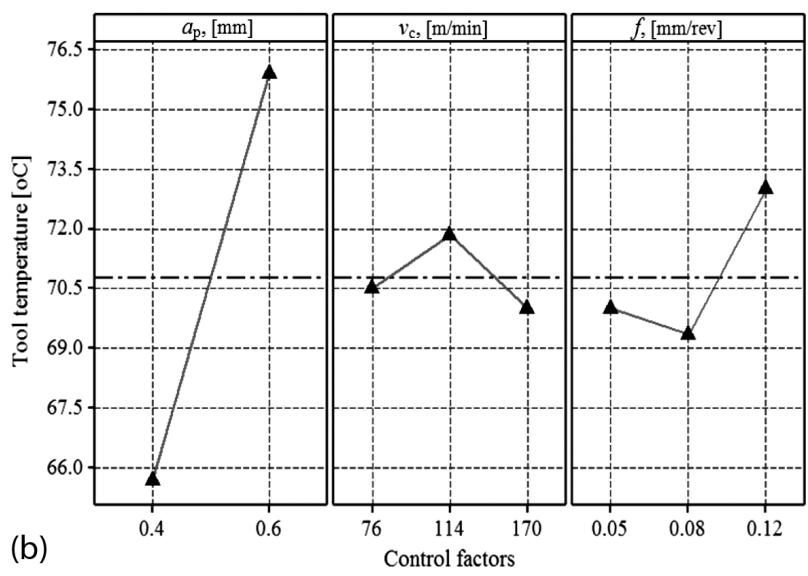

Figure 6: Mean effect plots for temperatures: a) tool-chip interface temperature, b) tool temperature

Slika 6: Diagram srednjega vpliva na temperature: a) temperatura stika orodje-ostružek, b) temperatura orodja $\mathrm{mm}), v_{1}\left(v_{\mathrm{c}}=76 \mathrm{~m} / \mathrm{min}\right)$ and $f_{3}(f=0.12 \mathrm{~mm} / \mathrm{rev})$,

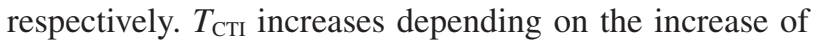
the cutting speed and the decrease of the depth of cut and the feed rate. From the same graphic it is clear that the most effective control factor on $T_{\text {СТ }}$ is the cutting speed. In Figure 7, the optimum levels of the control factors for the tool temperature are $a_{1}\left(a_{\mathrm{p}}=0.4 \mathrm{~mm}\right), v_{2}\left(v_{\mathrm{c}}=114\right.$ $\mathrm{m} / \mathrm{min})$ and $f_{2}(f=0.08 \mathrm{~mm} / \mathrm{rev})$, respectively.

In Figure 7, when the effects of the control factors on tool temperature were examined, a significant increase was observed on $T_{\mathrm{T}}$, depending on the increase in the depth of cut. With an increase of the cutting speed from $76 \mathrm{~m} / \mathrm{min}$ to $114 \mathrm{~m} / \mathrm{min}$ and an increase of the feed rate from $0.08 \mathrm{~mm} / \mathrm{rev}$ to $0.12 \mathrm{~mm} / \mathrm{rev}$ the tool temperature was increased (Figure 7). Similarly, the optimum levels for the minimum $R_{\mathrm{a}}$ surface roughness were observed to be $a_{2}\left(a_{\mathrm{p}}=0.6 \mathrm{~mm}\right), v_{3}\left(v_{\mathrm{c}}=170 \mathrm{~m} / \mathrm{min}\right)$ and $f_{1}(f=0.05$ $\mathrm{mm} / \mathrm{rev}$ ), respectively (Figure 5). The most effective parameter on $R_{\mathrm{a}}$ was the feed rate (Figure 7). With a further increase in the feed rate value the $R_{\mathrm{a}}$ surface roughness value increased.

ANOVA is a statistically based, objective, decisionmaking tool used for determining any difference in the average performance of a group of items being tested. ${ }^{15-18}$ In the case when the $F$ value of a process parameter is greater than the tabulated $F$ ratio, it shows that the control factor has a significant effect on the performance characteristic. An analysis of variance (ANOVA) with a $95 \%$ confidence interval was carried out for each experiment using the $\mathrm{L}_{18}$ orthogonal array in order to determine the effects of the control factors and their interactions on selected performance/quality characteristics. The results of the ANOVA carried out for $T_{\mathrm{CTI}}, T_{\mathrm{T}}$ and $R_{\mathrm{a}}$ are presented in Tables 7, 8 and 9 . The cutting speed became the most effective factor for the tool-chip interface temperature, with a contribution of $86.57 \%$ followed by the feed rate with $4.03 \%$ (Table 7). The effects of other control factors and their interactions on $T_{\text {CTI }}$ became insignificant with a smaller $5 \%$ contribution (Table 7). The results of the ANOVA for the tool

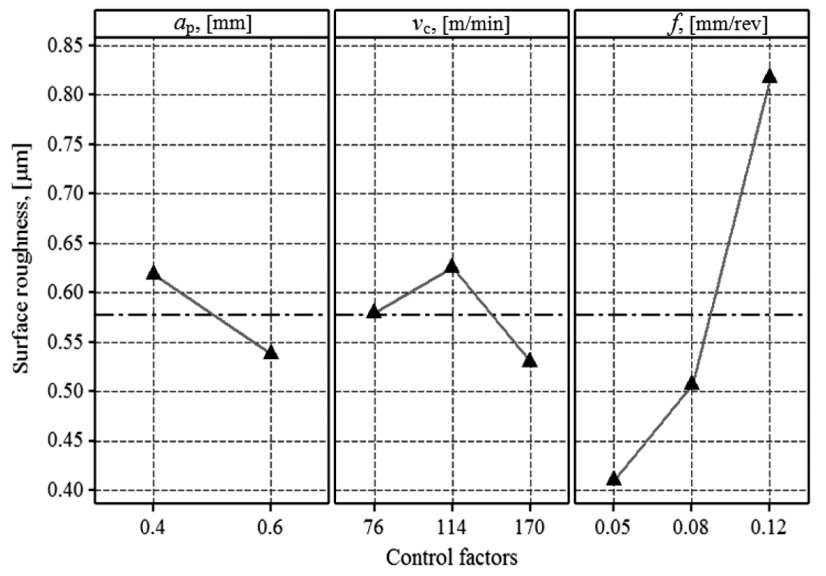

Figure 7: Mean effect plots for $R_{\mathrm{a}}$ surface roughness

Slika 7: Diagrami srednjega vpliva na hrapavost površine $R_{\mathrm{a}}$ 
temperature $\left(T_{\mathrm{T}}\right)$ indicate that the depth of cut $\left(a_{\mathrm{p}}\right)$ has more influence on the tool temperature, with a contribution of $52.65 \%$ and a cutting speed-feed rate $(v \times f)$ $16.75 \%$, depth of cut-cutting speed $(a \times v) 9.12 \%$, depth of cut-feed rate $(a \times f) 7.51 \%$, feed rate $(f) 5.13 \%$ and cutting speed $\left(v_{\mathrm{c}}\right) 1.21 \%$ followed by a contribution $\%$, respectively (Table 8). Finally, from Table 9, it is concluded that the feed rate with a contribution of $76.63 \%$ has more influence on the surface roughness $\left(R_{a}\right)$ followed by the depth of cut-feed rate $(a \mathrm{x} f)$, the depth of cut $\left(a_{\mathrm{p}}\right)$ and the cutting speed $\left(v_{\mathrm{c}}\right)$ to obtain the minimum surface roughness (Table 9).

Table 7: Results of ANOVA for tool-chip interface temperature $\left(T_{\mathrm{CTI}}\right)$ Tabela 7: Rezultati ANOVA za temperaturo stika orodje-ostružek $\left(T_{\mathrm{CTI}}\right)$

\begin{tabular}{|c|c|c|c|c|c|c|}
\hline Source & DoF & SS & V & $F$-Ratio & Prob. $>F$ & $\begin{array}{c}\text { Contr. } \\
(\%)\end{array}$ \\
\hline$a_{\mathrm{p}}$ & 1 & 672.3 & 672.2 & 3.44 & 0.137 & 2.08 \\
\hline$v_{\mathrm{c}}$ & 2 & 27986.1 & 13993.1 & 71.71 & 0.001 & 86.57 \\
\hline$f$ & 2 & 1302.8 & 651.4 & 3.34 & 0.140 & 4.03 \\
\hline$a \times v$ & 2 & 302.8 & 151.4 & 0.78 & 0.519 & 0.94 \\
\hline$a \mathrm{x} f$ & 2 & 369.4 & 184.7 & 0.95 & 0.461 & 1.14 \\
\hline$v \mathrm{x} f$ & 4 & 913.9 & 228.5 & 1.17 & 0.441 & 2.83 \\
\hline Res.Err. & 4 & 780.6 & 195.1 & & & 2.41 \\
\hline Total & 17 & 32327.8 & & & & 100.00 \\
\hline
\end{tabular}

$R^{2}=97.6, R^{2}(\operatorname{adj})=89.7($ significant at $95 \%$ confidence level $)$

Table 8: Results of ANOVA for tool temperature $\left(T_{\mathrm{t}}\right)$

Tabela 8: Rezultati ANOVA za temperaturo orodja $\left(T_{\mathrm{t}}\right)$

\begin{tabular}{|c|c|c|c|c|c|c|}
\hline Source & DoF & SS & V & $F$-Ratio & Prob. $>F$ & $\begin{array}{c}\text { Contr. } \\
(\%)\end{array}$ \\
\hline$a_{\mathrm{p}}$ & 1 & 470.22 & 470.22 & 27.57 & 0.006 & 52.65 \\
\hline$v_{\mathrm{c}}$ & 2 & 10.78 & 5.389 & 0.32 & 0.746 & 1.21 \\
\hline$f$ & 2 & 45.78 & 22.889 & 1.34 & 0.358 & 5.13 \\
\hline$a \mathrm{x} v$ & 2 & 81.44 & 40.722 & 2.39 & 0.208 & 9.12 \\
\hline$a \mathrm{x} f$ & 2 & 67.11 & 33.556 & 1.97 & 0.254 & 7.51 \\
\hline$v \mathrm{x} f$ & 4 & 149.56 & 37.389 & 2.19 & 0.233 & 16.75 \\
\hline Res.Err. & 4 & 68.22 & 17.056 & & & 7.64 \\
\hline Total & 17 & 893.11 & & & & 100.00 \\
\hline
\end{tabular}

$R^{2}=92.4, R^{2}(\operatorname{adj})=67.5($ significant at $95 \%$ confidence level $)$

Table 9: Results of ANOVA for surface roughness $\left(R_{\mathrm{a}}\right)$ Tabela 9: Rezultati ANOVA za hrapavost površine $\left(R_{\mathrm{a}}\right)$

\begin{tabular}{|c|c|c|c|c|c|c|}
\hline Source & DoF & SS & V & $F$-Ratio & Prob. $>F$ & $\begin{array}{c}\text { Contr. } \\
(\%)\end{array}$ \\
\hline$a_{\mathrm{p}}$ & 1 & 0.028880 & 0.028880 & 10.73 & 0.031 & 4.18 \\
\hline$v_{\mathrm{c}}$ & 2 & 0.027281 & 0.013641 & 5.07 & 0.080 & 3.95 \\
\hline$f$ & 2 & 0.543172 & 0.271586 & 100.89 & 0.000 & 78.63 \\
\hline$a \times V$ & 2 & 0.014830 & 0.007415 & 2.75 & 0.177 & 2.15 \\
\hline$a \times f$ & 2 & 0.062656 & 0.031328 & 11.64 & 0.022 & 9.07 \\
\hline$V \times f$ & 4 & 0.003192 & 0.000798 & 0.30 & 0.867 & 0.46 \\
\hline Res.Err. & 4 & 0.010767 & 0.002692 & - & - & 1.56 \\
\hline Total & 17 & 0.690779 & - & - & - & 100.00 \\
\hline
\end{tabular}

$R^{2}=98.4, R^{2}($ adj $)=93.4$ (significant at $95 \%$ confidence level)

\subsection{Developed second-order predictive equations for the temperature and surface roughness}

The equations that were developed with multiple linear regression analysis to predict $T_{\mathrm{CTI}}, T_{\mathrm{T}}$ and $R_{\mathrm{a}}$ in the turning of quenched and tempered AISI 4140 steel with coated carbide cutting tools and the equations that contain the main effects of the control factors and their interaction effects are presented in Equations (3) to (5), respectively.

$T_{\text {CTI }}=382-146 a+0.966 v+179 f+0.708 a v-3.58 v f$

$T_{\mathrm{T}}=2.0-96.8 a+0.328 v+255 f-0.381 a v-1.74 v f$

$R_{\mathrm{a}}=-0.114-0.34 a+0.00332 v+7.15 f-$

$$
-0.00617 a v-0.0102 v f
$$

These equations were developed according to the un-coded values of the control factors (i.e., 0.4, $0.6 \mathrm{~mm}$, etc. for $a_{\mathrm{p}}$; i.e., 76, 114, $170 \mathrm{~m} / \mathrm{min}$, etc. for $v_{\mathrm{c}}$; i.e., 0.05 , $0.08,0.012 \mathrm{~mm} / \mathrm{rev}$, etc. for $f$ ). af is highly correlated with other variables, so af has been removed from all of the equations. The correlation coefficients $\left(R^{2}\right)$ and the adjusted correlation coefficients $\left(R^{2}(\operatorname{adj})\right)$ of the secondorder equations developed for the predictive tool-chip interface temperature $\left(T_{\mathrm{CTI}}\right)$ measured with an IR pyrometer, the tool temperature $\left(T_{\mathrm{T}}\right)$ measured with a thermocouple and the surface roughness $\left(R_{\mathrm{a}}\right)$ were calculated as $R^{2}=92.8 \%, R^{2}(\operatorname{adj})=89.8 \%, R^{2}=68.1 \%, R^{2}(\operatorname{adj})=$ $54.8 \%$ and $R^{2}=82.6 \% R^{2}$ (adj) $=75.3 \%$, respectively. $R^{2}$ (adj) determines the amount of deviation about the mean that is described by the model. The predicted $R^{2}$ value and the $R^{2}$ (adj) value were found to be in good agreement. These values show that the equations developed are sufficient to determine all the response values at a confidence interval of $95 \%$. The regression models can be successfully adopted for estimating $T_{\text {СТI }}, T_{\mathrm{T}}$ and $R_{\mathrm{a}}$. Moreover, as seen in these equations, $v_{\mathrm{c}}$ and $f$ have additive effects, while $a_{\mathrm{p}}$ has a negative effect on $T_{\mathrm{CTI}}, T_{\mathrm{T}}$ and $R_{\mathrm{a}}$.

The comparisons of the results of $T_{\mathrm{CTI}}, T_{\mathrm{T}}$ and $R_{\mathrm{a}}$ measured experimentally (Table 4) with the fits for $T_{\mathrm{CTI}}$, $T_{\mathrm{T}}$ and $R_{\mathrm{a}}$ estimated via the Taguchi method and fits for $T_{\mathrm{CTI}}, T_{\mathrm{T}}$ and $R_{\mathrm{a}}$ estimated via the Regression model (Equation (3) to (5)) are given in Table 8. As can be seen from this table, the $T_{\text {CTI }}$ results obtained from the Taguchi method and the linear regression analysis were found to be very close. The mean of the \% error ratios of the estimated results obtained by the Taguchi method and the predictive equations were less than $14 \%$. This reflects the reliability of the statistical analyses (Tables 10 and 11).

\section{CONCLUSIONS}

In this study, the Taguchi design was selected to determine the effects of the control factors. The effects of the depth of cut, the cutting speed and the feed rate on the tool-chip interface temperature $\left(T_{\mathrm{CTI}}\right)$, the tool 
A. R. MOTORCU et al.: ANALYSIS OF THE CUTTING TEMPERATURE AND SURFACE ROUGHNESS ...

Table 10: The comparisons of measured of $T_{\mathrm{CTI}}$, and $T_{\mathrm{t}}$ experimentally with fits estimated via the Taguchi method and regression models Tabela 10: Primerjava izmerjenih $T_{\mathrm{CTI}}$ in eksperimentalnih $T_{\mathrm{t}}$, z ujemanji, določenimi po Taguchi metodi in $\mathrm{z}$ regresijskimi modeli

\begin{tabular}{|c|c|c|c|c|c|c|c|c|c|c|}
\hline \multirow[b]{2}{*}{$\begin{array}{c}\text { Exp. } \\
\text { no }\end{array}$} & \multicolumn{5}{|c|}{ Tool-chip interface temperature, $T_{\mathrm{CTI}}\left({ }^{\circ} \mathrm{C}\right)$} & \multicolumn{5}{|c|}{ Tool temperature, $T_{\mathrm{t}}\left({ }^{\circ} \mathrm{C}\right)$} \\
\hline & $\begin{array}{l}\text { Meas- } \\
\text { ured } \\
T_{\text {CTI }}\end{array}$ & $\begin{array}{l}\text { Fits for } T_{\text {СTI }} \\
\text { estimated via } \\
\text { Taguchi method }\end{array}$ & $\begin{array}{c}\text { Error } \\
\%\end{array}$ & $\begin{array}{c}\text { Fits for } T_{\mathrm{CTI}} \\
\text { estimated via } \\
\text { Regression model }\end{array}$ & $\begin{array}{c}\text { Error } \\
\%\end{array}$ & $\begin{array}{c}\text { Meas- } \\
\text { ured } \\
T_{\mathrm{t}}\end{array}$ & $\begin{array}{c}\text { Fits for } T_{\mathrm{t}} \\
\text { estimated via } \\
\text { Taguchi method }\end{array}$ & $\begin{array}{c}\text { Error } \\
\%\end{array}$ & $\begin{array}{c}\text { Fits for } T_{\mathrm{t}} \\
\text { estimated via } \\
\text { Regression model }\end{array}$ & $\begin{array}{c}\text { Error } \\
\%\end{array}$ \\
\hline 1 & 410 & 418 & 2.0 & 414 & 0.9 & 57 & 56 & 1.0 & 60 & 5.7 \\
\hline 2 & 405 & 401 & 0.9 & 411 & 1.4 & 66 & 68 & 2.9 & 64 & 3.2 \\
\hline 3 & 410 & 406 & 1.1 & 407 & 0.7 & 72 & 71 & 1.9 & 69 & 4.5 \\
\hline 4 & 460 & 462 & 0.5 & 454 & 1.3 & 65 & 62 & 3.9 & 64 & 2.1 \\
\hline 5 & 465 & 458 & 1.5 & 447 & 3.8 & 61 & 61 & 0.1 & 65 & 7.0 \\
\hline 6 & 425 & 430 & 1.1 & 438 & 3.1 & 67 & 70 & 3.9 & 68 & 0.8 \\
\hline 7 & 520 & 510 & 2.0 & 514 & 1.1 & 65 & 68 & 4.8 & 69 & 5.5 \\
\hline 8 & 500 & 511 & 2.1 & 501 & 0.2 & 67 & 65 & 2.8 & 67 & 0.5 \\
\hline 9 & 475 & 475 & 0.1 & 484 & 1.9 & 71 & 70 & 1.7 & 66 & 7.5 \\
\hline 10 & 400 & 392 & 2.0 & 395 & 1.2 & 72 & 73 & 0.8 & 74 & 2.5 \\
\hline 11 & 390 & 394 & 0.9 & 392 & 0.6 & 80 & 78 & 2.4 & 77 & 3.1 \\
\hline 12 & 395 & 399 & 1.1 & 389 & 1.6 & 76 & 77 & 1.8 & 82 & 8.4 \\
\hline 13 & 430 & 428 & 0.5 & 441 & 2.6 & 80 & 83 & 3.2 & 74 & 7.1 \\
\hline 14 & 435 & 442 & 1.6 & 434 & 0.2 & 75 & 75 & 0.1 & 76 & 1.3 \\
\hline 15 & 420 & 415 & 1.1 & 425 & 1.2 & 83 & 80 & 3.1 & 78 & 5.8 \\
\hline 16 & 485 & 495 & 2.1 & 509 & 4.9 & 81 & 78 & 3.8 & 75 & 7.4 \\
\hline 17 & 525 & 514 & 2.0 & 496 & 5.5 & 67 & 69 & 2.8 & 74 & 10.1 \\
\hline 18 & 480 & 480 & 0.1 & 479 & 0.2 & 69 & 70 & 1.8 & 72 & 4.5 \\
\hline Min & 390 & 392 & 0.1 & 389 & 0.2 & 57 & 56 & 0.1 & 60 & 0.5 \\
\hline Max & 525 & 514 & 2.1 & 514 & 5.5 & 83 & 83 & 4.8 & 82 & 10.1 \\
\hline Mean & 446 & - & 1.3 & - & 1.8 & 71 & - & 2.4 & - & 4.8 \\
\hline
\end{tabular}

Table 11: The comparisons of the measured $R_{\mathrm{a}}$ with fits estimated via the Taguchi method and the regression models Tabela 11: Primerjava izmerjene $R_{\mathrm{a}} \mathrm{z}$ ujemanji, določenimi po Taguchi metodi in z regresijskimi modeli

\begin{tabular}{|c|c|c|c|c|c|}
\hline Exp.no & Measured $R_{\mathrm{a}}$ & $\begin{array}{l}\text { Fits for } R_{\mathrm{a}} \text { estimated via } \\
\text { Taguchi method }\end{array}$ & Error \% & $\begin{array}{l}\text { Fits for } R_{\mathrm{a}} \text { estimated via } \\
\text { Regression model }\end{array}$ & Error $\%$ \\
\hline 1 & 0.295 & 0.338 & 14.4 & 0.406 & 37.5 \\
\hline 2 & 0.483 & 0.478 & 1.1 & 0.597 & 23.5 \\
\hline 3 & 0.958 & 0.921 & 3.9 & 0.851 & 11.1 \\
\hline 4 & 0.484 & 0.461 & 4.7 & 0.418 & 13.5 \\
\hline 5 & 0.579 & 0.594 & 2.5 & 0.598 & 3.3 \\
\hline 6 & 0.988 & 0.996 & 0.8 & 0.837 & 15.3 \\
\hline 7 & 0.410 & 0.390 & 4.9 & 0.438 & 6.7 \\
\hline 8 & 0.492 & 0.483 & 1.9 & 0.600 & 21.9 \\
\hline 9 & 0.872 & 0.901 & 3.4 & 0.816 & 6.4 \\
\hline 10 & 0.489 & 0.446 & 8.7 & 0.380 & 22.3 \\
\hline 11 & 0.530 & 0.535 & 1.0 & 0.571 & 7.7 \\
\hline 12 & 0.720 & 0.757 & 5.2 & 0.826 & 14.7 \\
\hline 13 & 0.429 & 0.452 & 5.3 & 0.346 & 19.4 \\
\hline 14 & 0.547 & 0.532 & 2.7 & 0.525 & 4.0 \\
\hline 15 & 0.722 & 0.714 & 1.1 & 0.765 & 5.9 \\
\hline 16 & 0.354 & 0.374 & 5.7 & 0.296 & 16.5 \\
\hline 17 & 0.406 & 0.415 & 2.3 & 0.458 & 12.8 \\
\hline 18 & 0.643 & 0.614 & 4.6 & 0.674 & 4.9 \\
\hline Min & 0.295 & 0.338 & 0.8 & 0.296 & 3.3 \\
\hline Max & 0.988 & 0.996 & 14.4 & 0.851 & 37.5 \\
\hline Mean & 0.578 & - & 4.1 & - & 13.7 \\
\hline
\end{tabular}


temperature $\left(T_{\mathrm{T}}\right)$ and the surface roughness $\left(R_{\mathrm{a}}\right)$ were investigated in the turning of the quenched and normalized AISI 4140 steel workpieces that were machined using TiAlN-TiN, PVD-coated, carbide tools and the obtained results are as follows:

The most effective parameter on the tool-chip interface temperature was the cutting speed with a contribution ratio of $86.57 \%$. The effective parameters for tool temperature were the depth of cut, the cutting speed-feed rate, the depth of cut-cutting speed, the depth of cut-feed rate, the feed rate and the cutting speed with contributions of $52.65 \%, 16.75 \%, 9.12 \%, 7.51 \%, 5.13 \%$ and $1.21 \%$.

The feed rate with a contribution of $76.63 \%$ has more influence on the surface roughness $\left(R_{a}\right)$ followed by the depth of cut-feed rate $(a x f)$, the depth of cut $\left(a_{\mathrm{p}}\right)$ and the cutting speed $\left(v_{\mathrm{c}}\right)$ to obtain the minimum surface roughness.

The optimum levels of the control factors were $a_{\mathrm{p}}=$ $0.6 \mathrm{~mm}, v_{\mathrm{c}}=76 \mathrm{~m} / \mathrm{min}$ and $f=0.12 \mathrm{~mm} / \mathrm{rev}$ for the minimum tool-chip interface temperature; $a_{\mathrm{p}}=0.4 \mathrm{~mm}$, $v_{\mathrm{c}}=114 \mathrm{~m} / \mathrm{min}$ and $f=0.08 \mathrm{~mm} / \mathrm{rev}$ for the minimum tool temperature, and $a_{\mathrm{p}}=0.6 \mathrm{~mm}, v_{\mathrm{c}}=170 \mathrm{~m} / \mathrm{min}$ and $f=0.05 \mathrm{~mm} / \mathrm{rev}$ for the minimum $R_{\mathrm{a}}$ surface roughness.

The tool-chip interface temperature increased significantly depending on the increase of the cutting speed. The depths of cut and feed rate do not have a significant effect on the tool-chip interface temperature.

The tool temperature increased significantly depending on the increase of the depth of cut.

The surface roughness increased depending on the increase of the feed rate, while the same tendency was not observed for the depth of cut and the cutting speed.

The correlation coefficients of the predictive equations developed for the estimation of the minimum tool-chip interface temperature, the tool temperature and the surface roughness by multiple linear regression analysis were calculated as $0.928,0.681$ and 0.826 , respectively. Higher correlation coefficients reflect the reliability of the developed equations.

The mean of the $\%$ error ratios of the estimated results obtained by Taguchi method and the predictive equations were less than $14 \%$. This reflects the reliability of the statistical analyses.

\section{REFERENCES}

${ }^{1}$ X. L. Liu, D. H. Wen, Z. J. Li, L. Xiao, F. G. Yan, Cutting temperature and tool wear of hard turning hardened bearing steel, Journal of Materials Processing Technology, 129 (2002), 200-206, doi:10.1016/S0924-0136(02)00651-9

${ }^{2}$ N. A. Abukhshim, P. T. Mativenga, M. A. Sheikh, Investigation of heat partition in high speed turning of high strength alloy steel, International Journal of Machine Tools and Manufacture, 45 (2005), 1687-1695, doi:10.1016/j.ijmachtools.2005.03.008

${ }^{3}$ N. A. Abukhshim, P. T. Mativenga, M. A. Sheikh, Heat generation and temperature prediction in metal cutting: a review and implications for high speed machining, International Journal of Machine Tools and Manufacture, 46 (2006) 7-8, 782-800, doi:10.1016/ j.ijmachtools.2005.07.024

${ }^{4}$ A. H. Suhail, N. Ismail, S. V. Wong, N. A. Abdul Jalil, Optimization of cutting parameters based on surface roughness and assistance of workpiece surface temperature in turning process, American Journal of Engineering and Applied Sciences, 3 (2010) 1, 102-108, doi:10.3844/ajeassp.2010.102.108

${ }^{5}$ P. D. Berger, R. E. Maurer, Experimental design with applications in management, Engineering and The Sciences, 1th ed., Duxbury Press, USA 2001

${ }^{6}$ G. R. Henderson, Six sigma: Quality improvement with MINITAB, 2nd ed., John Wiley and Sons, England 2006, 452-460

${ }^{7}$ T. P. Ryan, Statistical methods for quality improvement, 2nd ed., John Wiley and Sons, USA 2000

${ }^{8}$ A. Mishra, A. Gangele, Application of Taguchi method in optimization of tool flank wear width in turning operation of AISI 1045 steel, Industrial Engineering Letters, 2 (2012) 8, 11-18

${ }^{9}$ M. S. Phadke, Quality engineering using design of experiment, quality control, Rebust design and Taguchi method, 1st ed., Warsworth and Books, California 1998

${ }^{10}$ W. H. Yang, Y. S. Tarng, Design optimization of cutting parameters for turning operations based on Taguchi method, Journal of Materials Processing Technology, 84 (1998), 122-129, doi:10.1016/S09240136(98)00079-X

${ }^{11}$ B. M. Gopalsamy, B. Mondal, S. Ghosh, Taguchi method and ANOVA: An approach for process parameters optimization of hard machining while machining hardened steel, Journal of Scientific and Industrial Research, 68 (2009) 8, 686-695

${ }^{12}$ F. Ficici, M. Kapsiz, M. Durat, Applications of Taguchi design method to study wear behaviour of boronized AISI 1040 steel, International Journal of Physical Sciences, 6 (2011) 2, 237-243

${ }^{13}$ M. Adinarayana, G. Prasanthi, G. Krishnaiah, Parametric analysis and multi objective optimization of cutting parameters in turning operation of AISI 4340 alloy steel with CVD cutting tool, International Journal of Research in Engineering and Technology, 3 (2014) 2, 449-456

${ }^{14}$ E. D. Kirby, A parameter design study in a turning operation using the Taguchi method, The Technology Interface, (2006), 1-14

${ }^{15}$ P. J. Ross, Taguchi techniques for quality engineering: Loss function, orthogonal experiments, parameter and tolerance design, McGrawHill, New York 1988

${ }^{16}$ D. C. Montgomery, Taguchi's contributions to experimental design and quality engineering, design and analysis of experiment, Wiley, Canada 1991

${ }^{17}$ E. Canyılmaz, F. Kutay, An alternative approach to analysis of variance in Taguchi method, Journal of the Faculty of Engineering \& Architecture of Gazi University, 18 (2003) 3, 51-63

${ }^{18}$ R. K. Roy, A primer on the Taguchi method, Van Nostrand Reinhold, New York 1990 